\title{
分類学習を用いた参加型モデリング手法の拡張 Extension of Companion Modeling Using Classification Learning
}

\author{
$\underset{\text { Daisuke Torii }}{\text { 大祐 }}$ \\ 京都大学情報学研究科社会情報学専攻 \\ Department of Social Informatics, Kyoto University \\ torii@kuis.kyoto-u.ac.jp, http://www.lab7.kuis.kyoto-u.ac.jp/ ${ }^{\text {torii/ }}$ \\ ブスケ
François Bousquet \\ フランス国際農業研究所 (CIRAD) \\ Centre de coopération internationale en recherche agronomique pour le développement \\ bousquet@cirad.fr \\ 石田 亨 \\ 京都大学情報学研究科社会情報学専攻 \\ Department of Social Informatics, Kyoto University \\ ishida@i.kyoto-u.ac.jp, http://www.lab7.kuis.kyoto-u.ac.jp/ ishida/
}

keywords: multiagent-based simulation, modeling, machine learning, classification learning, feature selection

\section{Summary}

Companion Modeling is a methodology of refining initial models for understanding reality through a role-playing game (RPG) and a multiagent simulation. In this research, we propose a novel agent model construction methodology in which classification learning is applied to the RPG log data in Companion Modeling. This methodology enables a systematic model construction that handles multi-parameters, independent of the modelers ability. There are three problems in applying classification learning to the RPG $\log$ data: 1) It is difficult to gather enough data for the number of features because the cost of gathering data is high. 2) Noise data can affect the learning results because the amount of data may be insufficient. 3) The learning results should be explained as a human decision making model and should be recognized by the expert as being the result that reflects reality. We realized an agent model construction system using the following two approaches: 1) Using a feature selction method, the feature subset that has the best prediction accuracy is identified. In this process, the important features chosen by the expert are always included. 2) The expert eliminates irrelevant features from the learning results after evaluating the learning model through a visualization of the results. Finally, using the RPG log data from the Companion Modeling of agricultural economics in northeastern Thailand, we confirm the capability of this methodology.

\section{1.は じめ に}

マルチェージェントシミュレーションは, 社会システ ムを理解・設計するための手段として活用され, 多くの研 究がなされている.モデル構築・精錬は既存の文献, 調査 データ,ビデオなどを利用して行うことが一般的である が [Gilbert 99, Helbing 00, Murakami 03] , 現害を十分 理解しモデルに反映するために，ロールプレイングゲー ム $(\mathrm{RPG})$ やユーザ参加型のシミュレーションを積極的 に利用して , 初期モデルを精錬する参加型モデリングと いう手法が研究されている [Bousquet 99, Gilbert 02] .

しかしながら，RPGやシミュレーションから得たデー 夕を分析する場合, 多くは, 専門家の仮説を元に, 統計 分析などを利用して仮説を構成する要素を個別に検証す るというものである.このような手法では, 分析自体が 個人の能力に依存するだけでなく，仮説に含まれないが 関連する可能性のある要素の分析は, 兴の数が多くなる
と手間がかかすずるため，網羅的に行われないのか現 実である、本研究では，このような現実に対処するため に , 参加型モデリングのモデリングプロセスに対し分類 学習を組み込むことで, RPG ログから体系的にモデルを 獲得する方法論を提案する . 得られたモデルにより専門 家による仮説を客観的に検証することが可能となる．分 類学習を利用する利点は, 人手では扱いきれないすべて の要素を機械により同時に扱うことができ，乥こから必 要な要素をバイアスという客観的指標により選別しモデ ルを構築できる点である．ゲーミングのログに対し機械 学習を利用する研究としては, U-MART[Kita 03] があ る.これは，人工市場を対象とした具体的なテストベッ ドシステムであり，人間とェージェントが同時に参加す るシミュレーション環境でエージェントが最適な取引戦 略を学習するものである.本研究は，RPG ログデータ からステイクホルダーの現実を反映したモデルを機械学 習により得ようとする点で, 手法の目的が異なる. 
本手法の分類学習問題としてのタスクは, RPG ログ データから RPG 参加者の意志決定を一般的に説明する 分類知識を獲得することである.多くの分類学習の適用 研究では大量のデータから意味のある分類知識を獲得す ることを目的とするのに対し, 本研究では, 決して十分 とは言えない量のデータから専門家が人間の意志決定と して認める分類知識を獲得することが目的となる . 単に RPG ログデータから生成した事例集合に対し学習アル ゴリズムを適用するだけでは目的を達成するのは難しく， 参加型モデリングのプロセスに対し，専門家知識を利用 した学習プロセスを適宜組み込むことが必要である。特 に，参加型モデリングの最初の過程で生成される専門家 の仮説 (初期モデル) を学習プロセスにうまく取り入れ ることか鍵となる .このような問題に対し, 本研究では, 分類学習 [Quinlan 86, Quinlan 93] に与える属性を専門 家知識を反映して絞り込むことで, 数が十分でない事例 集合からでも一般性が高く，かつ現実を適切に説明するモ デルを獲得する接近法を用いて，本手法を実現するエー ジェントモデル構築システムを実現した . 専門家知識を 利用して属性を絞り込む分類学習の手法としては, [石野 95]がある.これは，大量の属性・事例を持つアンケート データを対象に，必要な属性集合を機械学習と専門家の インタラクションにより得るものである. 専門家は学習 前に重要な属性に関する知識を持っていない，本研究で は, 専門家が事前知識として持っている重要な属性の候 補を利用し属性を絞り込む別の接近法を提案している .

以下，本論文では，まず参加型モデリングのプロセス について述べる．次に，参加型モデリングにおける機械 学習を用いたモデル構築手法と具体的に弚れを実現する システムを論じる、最後に，実際に，タイ東北部におけ る農業経済を扱った参加型モデリング [Vejpas 04] に対 し，本手法を適用した結果と光の考察を示す。

\section{2. 参加型モデリング}

\section{$2 \cdot 1$ 参加型モデリングのモデリングプロセス}

参加型モデリング (Participatory Modeling あるいは Companion Modeling) [Bousquit 99, Bousquit 02] は , ロールプレイングゲーム $(\mathrm{RPG})$ やマルチェージェント シミュレーションをステイクホルダーと共に繰り返し行 うことで, 現実をより深く理解し, 文献などから構築し た初期モデルを精錬していく手法である.最終的に，本 手法で獲得したモデルを利用したマルチェージェントシ ミュレーションにより，将来起こりうるべき現象を提示す ることで, ステイクホルダー間にある問題の解決や，政 府の施策策定に役立てられる。

图 1 に参加型モデリングにおけるモデリングプロセス を示す . 始めに , 文献やステイクホルダーに対する調査 を元に初期エージェントモデルが構築される．次に，ス テイクホルダーを取り巻く環境を再現したボード（図 2

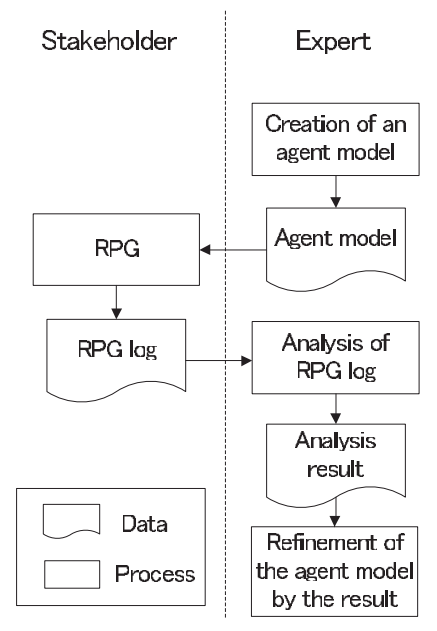

図 1 参加型モデリングにおける RPG を用いたモデリングプロセ ス [Bousquet 99]

左) を使用した RPG か実施される.RPG は,初期モデ ルを検査・改良するために行われる．RPGでは，ステイ クホルダーの意志決定の動機を明確にするためのインタ ビューが行われ，これらの情報と RPG データの解析に より元のエージェントモデルの改良が行われる.RPGが 行われた後に，RPGで使用されたボードと同じ特徵を 持つインタフェースを用いたマルチェージェントシミュ レーションが作成され (図 2 右)，ステイクホルダーに より評価が行われる.これは, 图 1 における RPG のプ ロセスをシミュレーションにより置き換えたプロセスと なる . ステイクホルダーは RPG の体験により，シミュ レーションを容易に理解可能であり，モデルの修正を示 唆することか河能である.多くの場合, 1 回以上 RPGに よるモデル構築が行われた後, 弚のモデルを使用してマ ルチェージェントシミュレーションによるモデルプロセ スが行われる.このように，RPGやシミュレーションを 用いたプロセスを繰り返し行うことで, 現実をより深く 理解していくことができる.

\section{$2 \cdot 2$ 参加型モデリングの特徵}

参加型モデリングの特徵は次の3つにまとめられ，現 実を反映したモデルの構筑とモデルの妥当性評価に対す る新しい解決法を与えている。

(1) RPG によりステイクホルダーが無意識に持つ問 題への理解を抽出でき，より現実を反映したモデル 構筑が行えること

(2) RPG と同じ特徵を持つシミュレーションが実現 されることにより，弚のモデル評価を専門的知識の ないステイクホルダー自身が行うことができること

(3) 最終的に行われる参加型モデリングにより獲得さ れたモデルを利用したマルチェージェントシミュレー ションは,ステイクホルダーがモデリングの過程を共 にしたことで , 現状から起こりえる教訓として捉え 

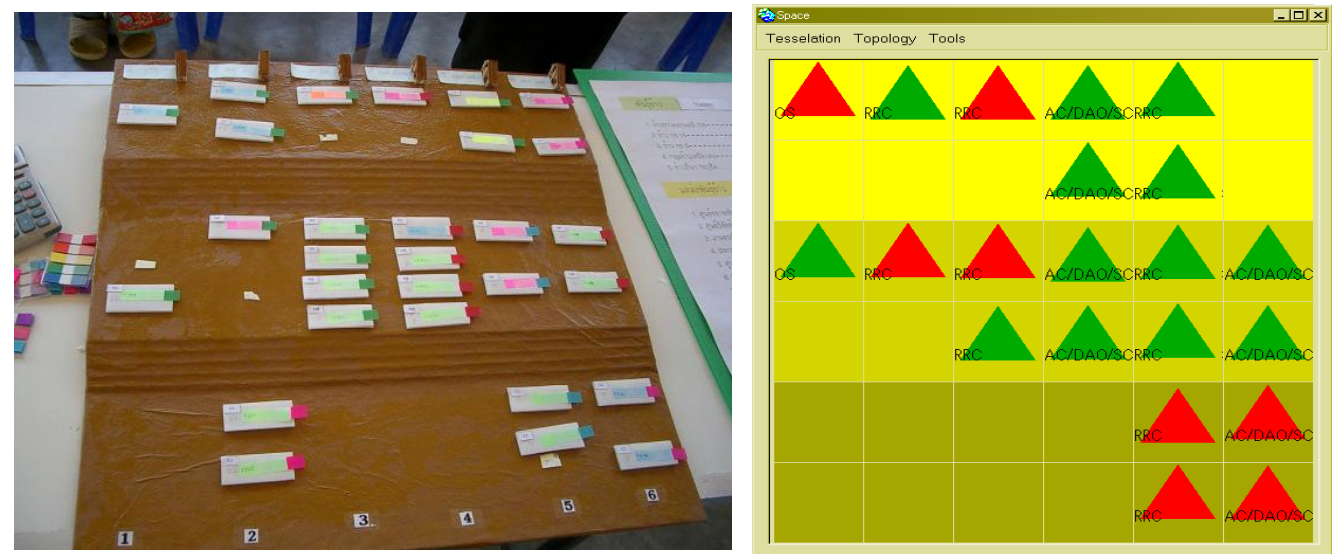

図 2 RPG ボード (左) とシミュレーションインタフェース (右) [Vejpas 04]

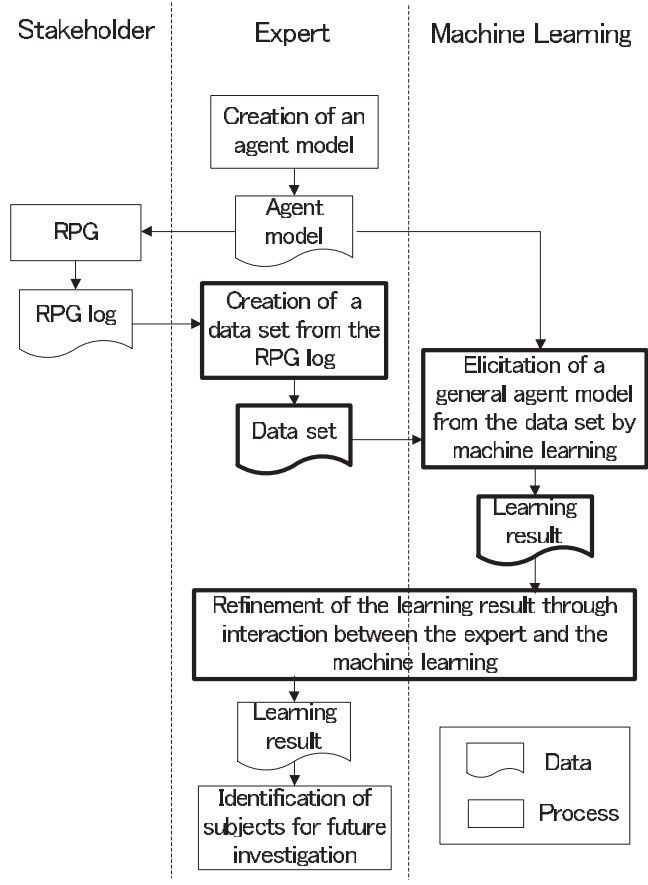

図 3 参加型モデリングの機械学習による拡張モデリングプロセス

ることができ，問題の解決に役立てることができる 特に, 東南アジアやアフリカなどの農村などで, 普段研 究のプロセスに慣れていないステイクホルダーを対象と したとしても，本方法は現実を抽出するための効果的な 方法と言える .

\section{3. 機械学習を用いた参加型モデリングの拡張}

本研究では，RPG ログデータを元に機械学習により モデルを獲得し，仮説として専門家が立てた意思決定モ デルを検証し，検討課題を得ることを目的とする．検証 のためには，仮説をある程度正しい前提知識として扱う 演繹学習ではなく，前提知識を必要とせず，データから 分類知識を抽出する分類学習が適切と言える.

本手法のタスクは, RPG ログデータからの分類学習
によって, $\mathrm{RPG}$ 参加者の意志決定を一般的に説明する分 類知識を獲得することである，弚のために，図 3 に示す 機械学習 (分類学習) を用いたエージェントモデル構築 プロセスを提案する . 提案手法は, 図 1 に示す $R P G$ を 用いたモデリングプロセスに適用・拡張したもので，人 手による RPG ログ分析部分を機械学習を用いたプロセ スで置き換えたものとなっている (図 3 中，太枠部) . 本 部分は, 次の 3 つの部分から構成される .

(1) 初期設定

RPG ログデータを機械学習で使用できる形式に変 換し，学習データを生成する。

(2) 機械学習による一般モデルの導出 専門家により生成された初期モデルと RPG ログデー タから変換された学習データから学習モデルを導出 する.ここで重要なのは，初期モデルを利用して専 門家知識を学習に対して反映することと，導いた学 習モデルができるだけ高い一般性を持つことである .

(3) 機械学習と専門家のインタラクションによる学習 モデルの精錬

上記手順により，専門家知識を反映した一般的モデ ルが出力されるものの, 専門家が十分納得し, 現実 を反映したモデルであるためには，専門家と機械学 習の間で適切なインタラクションを設計し, 学習モ デルをさらに精錬できることが必要となる．

4. 分類学習によるエージェントモデル構築シ ステム

本章では，前章で述べた手法を実現する具体的なシス テムの設計を示す .

\section{$4 \cdot 1$ 問 題 設 定}

分類学習問題としての特徵は次の 3 点である .

(1) 専門家は, 文献やサーベイを元に仮説を構築する ものの，仮説に含まれる意思決定の要因以外にも重 要な要因が存在すると考えている．事例データに含 
まれる属性は，弚のような専門家が分類に有効であ ると考えるすべて含ませるため，弚の数が大きくな る傾向にある．しかしながら，属性数か増えるほど 学習の性能を確保するのに必要な事例数が大きくな る傾向にある [Almuallim 94, Kohavi 97] のに対し， データ収集コストが高いために，学習で利用する属性 数に対し十分な学習データを得ることが困難である.

(2) データ量の不十分さゆえにノイズが学習結果に影 響を及ぼす可能性が高い .

(3) 学習から得た分類知識は, 単に新しい事例を正し く分類する性能も必要であるが, エージェントの意 思決定モデルとして説明がつくものである必要があ る.このことは，学習結果を構成する分類条件は，現 実を説明する適切な文脈を持ち，専門家を納得させ るものでなくてはならないということである .

\section{$4 \cdot 2$ 接 近 法}

以上の問題への我々の接近法は, 分類学習 (C4.5) [Quinlan 86, Quinlan 93] に与える属性を専門家知識を反映し て絞り込み, 数が十分でない事例集合からでも一般性が 高く，かつ現実を適切に説明するモデルを獲得するもの

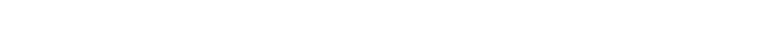

(1) 機械学習の側よりできるだけ不要な属性を削除し， より一般性の高いモデルを専門家に提供するために， Wrapper アプローチ ${ }^{* 1}[$ Kohavi 97] を利用する . 今 回は,交差検定 ${ }^{* 2}$ から導かれる予測精度 (Prediction Accuracy）を最大にする属性組を初期の属性組から 山登り法 (後向き探索) により除去していくことに より同定する . 性能推定に交差検定を利用すること で, 未知のデータに対して分類精度の高い (一般性 の高い）モデルを得ることができる．ただし，本手 法では, 事例数が十分でない場合，ノイズがあるた めに，現実を正しく説明するための必須属性も除外 される可能性がある．乥こで, 専門家により分類学 習適用前に作成される仮説 (決定木モデル) に含ま れる属性は，現実を正しく説明するために必要な要 素の候補として，この過程で除外しないようにする. (2) 学習結果を意思決定モデルとして説明できるもの とするために，不適切な属性を専門家により除去す ることで学習結果の精錬を行う. 学習結果が十分吟 味されるためには，専門家が直感的に理解できる提

\footnotetext{
*1 帰納学習により得られるモデルの性能が最良になるような属 性組を探索により求める手法.多くの場合，属性組の良し悪し を定義する性能推定値を交差検定から求め，山登り法を探索手 法として用い性能推定値を最良にする属性組を求める.山登り 法は , すべての属性組から初めて推定值が上がる方向に一つず つ属性を除外していく後向き探索と, 空集合から始めて推定値 が上がる方向に属性を追加していく前向き探索がある．

$* 2$ 重複を許さずに,訓練集合を $\mathrm{n}$ グループにほぼ等分割し, 光 のうち n-1 グループを利用して学習を行い, 残りの 1 グルー プでテストする.テスト事例を適用した予測精度を性能判定の 基準とする . テスト事例として選ぶ゙グループを変えながら本作 業を $\mathrm{n}$ 回行う.今回 , $\mathrm{n}$ は一般的に用いられている 10 とした
}

示法が必要である.乥こで, 実施した RPG と同じ 環境と参加者をコンピュータ上でグラフィカルイン タフェースとェージェントとして再現し, 弚の条件 下でェージェントに学習モデルを与え, エージェン 卜の意志決定結果として示すことて理解促進を图る。 弚の後, コンピュータ上の現象と決定木を照らし合 わせることで不適切な属性を同定する．この方法の 利点は, 最初から決定木を評価した場合, 専門家の 初期仮説を正しいものとして単に学習モデルを批判 しがちであるのに対し，エージェントの意思決定結 果として見せることにより中立的に評価を行える点 である,さらに，この評価をもとに決定木を再評価 し，十分吟味を尽くすことができる.尚，この点を 追求するために, 学習モデルに加え, 実際の RPG ログを弚のままェージェントに与えた場合も提示す る(どちらが学習モデルによるものかは専門家に伝 えない）.また，もう一つの利点は，可視化手法は 明らかにおかしな現象を容易に把握でき，不適切な 属性の発見が簡単に行える点である.

\section{$4 \cdot 3$ 分類学習を用いたモデル構築システム}

上記に述べた接近法を組み込んだモデル構筑システム を图 4 に示す . 以下に，3 章で述べた手法に対応した 3 つの手順における各処理を示す．

(1) 初期設定

決定木学習に用いる属性と目標概念を決定後, RPG ログから決定された属性に対応したインスタンスを 抽出し，事例集合を生成する．また，初期エージェ ントモデルを決定木モデルに変換し, 乥こに含まれ る属性を重要な属性として抽出する。

（2）属性選択手法による不要な属性の除外 初期設定で作成された属性と事例集合を用いて予測 精度が最良となる属性組を同定する. 属性選択探索 法は山登り法 (後向き探索), 性能推定值は交差検定 による予測精度を利用する．各段階では, 現属性集 合から一つ属性を除外して得られるすべてのパター

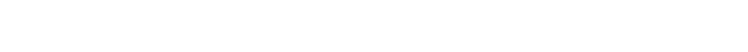
測精度を得る . 谷のうち最も予測精度が改善するも のがあれば，弚れを次の属性集合とする. 予測精度 の向上が得られなくなった時点で探索を終了し，光 のときの属性集合を出力する.ただし, 各段階で, 専 門家により選ばれた重要な属性は除外されない .

(3) 可視化による専門家への理解促進と精錬 最初に生成された事例集合と属性選択手法から得た 属性集合から学習結果を得る ( 3 章との対応として は，ここで2 番目の手順が終了する) . 次に, 実施 した RPG と同じ環境と参加者をコンピュータ上で グラフィカルインタフェースとェージェントとして 再現する.さらに, エージェントに学習モデルを与 えた場合と RPG ログを与えた場合の 2 通りを，ど 


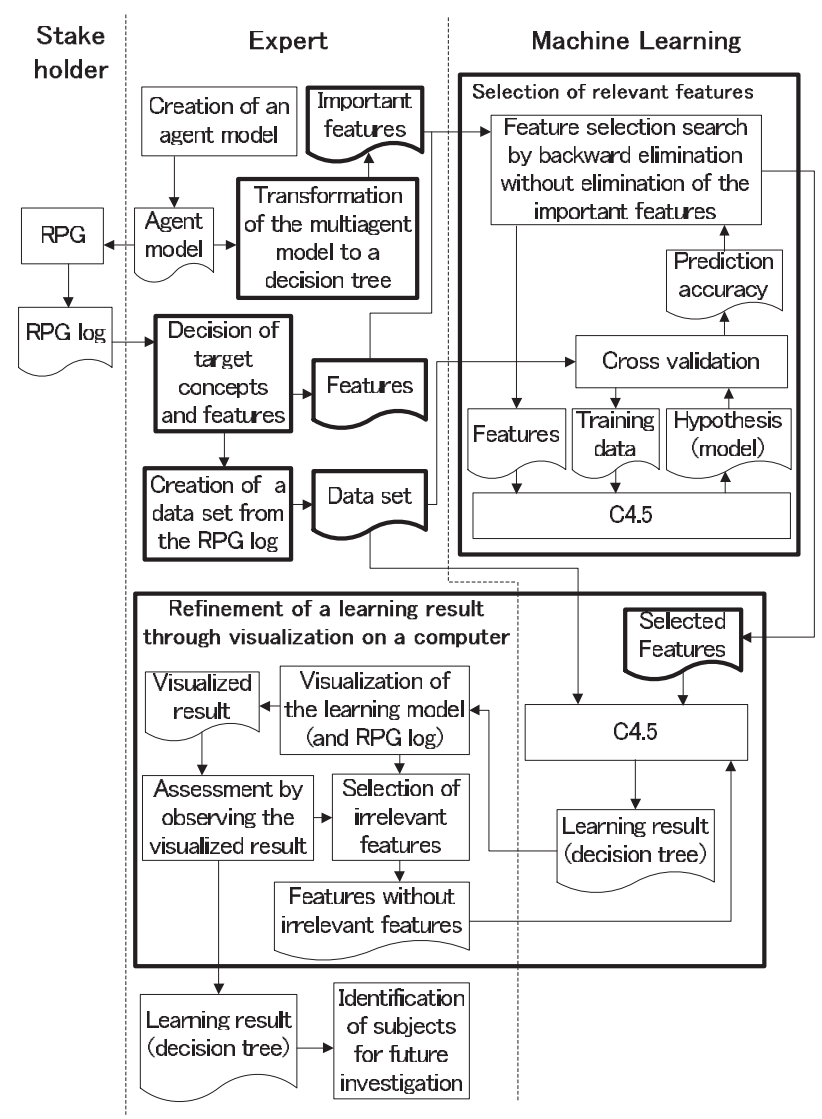

図 4 分類学習によるモデル構築システム

ちらか明かさずにェージェントの意志決定結果とし て専門家に提示し光れ光れの評価を得る．光の後， 専門家はどちらが学習モデルによるものであったか を知った上で, 兴の評価を元に直接決定木を吟味す る.もし不適切な属性があれば, 弚れか除外され再 びC 4.5 が適用される. 本プロセスは専門家が満足す るモデルを得るまで繰り返えされる . 本プロセス後 に，学習結果と仮説を検証し新たな検討対象を得る。

\section{5. 実データを利用した本手法の適用と評価}

\section{$5 \cdot 1$ 本研究における参加型モデリングプロジェクト}

本研究では, IRRI (国際稲研究所) ${ }^{* 3}$ と CIRAD (国 際農業開発センター) ${ }^{* 4}$ のタイ東北部における農業経済 を扱った共同プロジェクトに参加した [Vejpas 04] .

本参加型モデリングの背景は次の通りである . タイ東 北部において, タイ政府は数種類の米種を重点的に流通 させることに成功したが，一方で，一部ではこれまで使 用されてきた別の米種も未だに使用されている．また， 重点的な米種を流通させるために政府の補助により新た な米種提供業者の参入を容認している . 本参加型モデリ ングでは，1) 米種に関する農民のニーズと米種選択のモ デル獲得の把握すること，2) 農民の米種提供業者の選択

*3 http://www.irri.org/

*4 http://www.cirad.fr/
表 1 属性候補と炎の選択過程 : 5.2 節の 3 つの各手順で選択され た属性 (表中，“s”にて示す) と除外された属性 (表中 , “d” にて示す) を示す.尚，数字は手順を順番に表す．手順 1 で は専門家により重要と見なされた属性 (図 5 参照)，手順 2 では Wrapper 手法ににより除外された属性と C4.5 が出力 した結果に含まれる属性 (図 6 左参照)，手順 3 では専門家 により除外された属性と最終的に C4.5 が出力した結果に含 まれる属性 (図 6 右参照) を示す。

\begin{tabular}{|l|l|c|c|c|}
\hline 属性名 & 説明 & 1 & 2 & 3 \\
\hline Change Variety & $\begin{array}{l}\text { 前年度に作付けしなかつ } \\
\text { た米種を作付けするか }\end{array}$ & $\mathrm{s}$ & & \\
\hline $\begin{array}{l}\text { Original Supplier is } \\
\text { RRC }\end{array}$ & $\begin{array}{l}\text { 現在保持の米種が RRC } \\
\text { から仕入れたのか }\end{array}$ & $\mathrm{s}$ & & \\
\hline Previous Seed Class & 前年度使用の米種の等級 & $\mathrm{s}$ & $\mathrm{s}$ & $\mathrm{s}$ \\
\hline Close to Ubon & $\begin{array}{l}\text { 居 住 地 域 が Ubon } \\
\text { Ratchathani に近いか }\end{array}$ & $\mathrm{s}$ & $\mathrm{s}$ & $\mathrm{s}$ \\
\hline Accessibility of RRC & RRC から仕入れ可能か & $\mathrm{s}$ & $\mathrm{s}$ & $\mathrm{s}$ \\
\hline Farmer Name & 参加者 ID & & $\mathrm{d}$ & \\
\hline Step & ステップ & & & \\
\hline Ethnicity & 参加者が属する民族 & & & \\
\hline Family Number & 家族数 & & & \\
\hline Accessibility of SC & SC から仕入れ可能か & & & \\
\hline Total Size of Land & 農地の合計 & & & \\
\hline Size of Upper Land & 高地の面積 & & & \\
\hline Size of Middle Land & 中地の面積 & & $\mathrm{d}$ & \\
\hline Size of Lower Land & 低地の面積 & & & \\
\hline Previous Supplier & 前ステップで選択の業者 & & $\mathrm{d}$ & \\
\hline Original Supplier & $\begin{array}{l}\text { 現在保持する米種の仕入 } \\
\text { れ先業者 }\end{array}$ & & $\mathrm{s}$ & $\mathrm{d}$ \\
\hline
\end{tabular}

モデルと米種提供業者間の米種流通モデルを得ることで， 現在の米種提供システムの問題点を同定すること，の 2 点を目的としている .

我々は, 複数の品種の光れ光れに, 農民の米種選択の 選択モデルと米種提供業者の選択モデルを対象として本 手法を適用した . 本論文では，商業用に広く流通してい る米種に関する米種提供業者の選択モデルを例に示す．

\section{$5 \cdot 2$ 分類学習によるモデル構築システムの適用}

$4 \cdot 3$ 節の図 4 で示したシステムを本例題に適用する.初 期の全属性候補と各手順で専門家や機械学習により選択 /削除された属性を表 1 に示す．また，モデルの説明は 图 5, 图 6 中に付与された説明を参照のこと.

\section{$\S 1$ 初期設定}

専門家により属性と目標概念 (米種業者) の決定が行 われ，RPG ログ (2 回分 . 乥れ光れ都市部と農村部で行 われた）より事例集合が生成された．事例は，RPGにお ける各ステップ (一年に相当) における選択を表す．属 性数は 16 , 事例数は 80 となった ${ }^{* 5}$. また, 専門家の仮 説であるエージェントモデルが決定木モデルに変換され （図 5)，乥こから重要な属性が5つ抽出された .この決定 木で本事例集合を分類した際の精度は，58.0\%であった．

本仮説の概要は次の通りである.まず, Sub Tree (Own Stock (OS) を利用しない場合の純粋な業者の選択モデ ルと見なせる) では, 都市部 (Ubon Ratchathani 近郊) においては，最良の品質を提供する RRC から仕入れる

*5 最初のステップは全員が業者から調達するという特殊な状況 であり事例集合からは除外されている . 
ためには光の仕入れルートを特別に持っている必要があ る.尚，都市より離れている場合，専門家は業者がどのよ うに決定されるかは不明である . 次に , メインの決定木 では，まず，前年度に作付けしなかった品種を利用する 場合は, 弚の品種を他から仕入れる必要があり (OS 選択 不可)，“Change Variety" が分類条件となる．光れ以外 の場合は，Own Stock を使うか，業者から仕入れるかを 決定する．これには基本的に，前年使用した米の等級を 表す "Previous Seed Class" の值 (0が最もよい等級で ある) が影響するが，元々自分が仕入れた米種が品質の 良いRRCであれば，より OS を長く使い続ける (RRC から仕入れた場合は 3 年間).

\section{$\S 2$ 属性選択手法による不要な属性の除外}

事例集合と属性を利用して，4・3 節 (2) で述べた属性 選択を行った . 即ち , 16 個すべての属性組から始め, 山 登り法 (後向き探索)により，交差検定から得た予測精 度がこれ以上上がらなくなるまで属性を一つずつ削除し ていった . 弚の際に, $5 \cdot 2 \cdot 1$ 節で選定された重要な属性 5 つは削除対象外となり，残りの 11 個の属性から削除が 行われた . 弚の結果，予測精度は初期の $66.2 \%$ から，3 つの属性か除外された結果 $71.2 \%$ となった。

\section{$\S 3$ 可視化による専門家への理解促進と精錬}

最初に生成された事例集合と属性選択手法から得た 11 個の属性から $\mathrm{C} 4.5$ により学習モデルを導出した (図 6 左).次に，可視化手法のために，RPGで使用したボー トの特徵をグラフィカルインタフェースとして, $\mathrm{RPG}$ 参 加者をエージェントとして, Cormas ${ }^{* 6}[$ Bousquit 98] 上 で実装した (図 2 右) .さらに,エージェントに対して 学習モデル (図 6 左) と RPG ログを与えた光れどれの 場合に対して，コンピュータ上でェージェントの意志決 定結果として専門家に示していった . 専門家はステップ (一年分に相当) ごとに，各ェージェントの意志決定結果 に対して見解を記録しながら注意深く観察していった .

兴の後, どちらが学習モデルによるものであったか明 かした上で, 図 6 (左) の決定木を直接専門家に見せる ことで評価が行われ，現実に即さない不適切な属性の選 出が行われた . 専門家は, 自分たちが述べた見解と決定 木を照らし合わせることで，コンピュータ上で起こった 現象の原因を理解することができた . 今回は, 農村部の 農民に関しては，第一ステップに一部が “ST”を選び， それ以降のステップではすべて "OS”が選択されたとい う特徵的な”状況が観察され，弚の原因である “Original Supplier”が不適切な属性と判断された .なぜならば，住 む場所がどこであれ，自分が所持する米種の元々の仕入 れ先のみが業者の選択を決定するものとはなりえないか らである(この属性は，Own Stock を使用し続ける年数 「Seed Class」のみに影響する以外ほとんど考えられない というのが尃門家の一致した見解であった）．したがっ て，この属性を除去し，再び，C4.5 の適用を行った . 弚

*6 http://cormas.cirad.fr/indexeng.htm

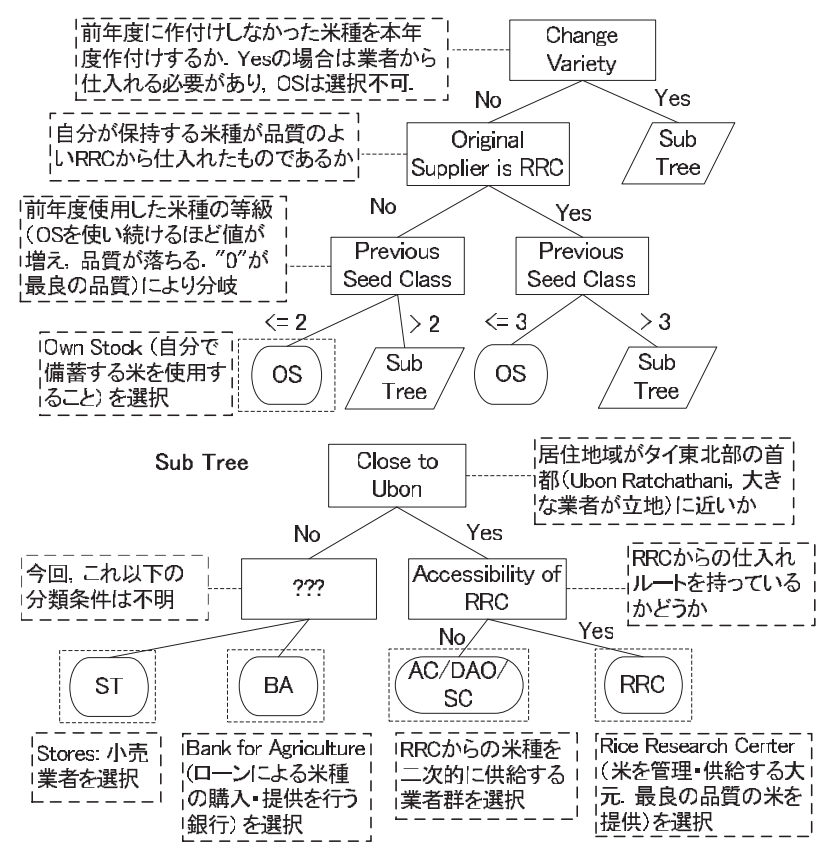

図 5 専門家により作成された決定木 (初期仮説)

の結果を図 6 (右) に示す .再度専門家の評価により問題 がなかったので，これを最終的なモデルとした．尚，予 測精度は $68.8 \%$, 分類精度は $75.0 \%$ となった。

\section{$5 \cdot 3$ 仮 説 の 検 証}

最終的なモデルは, RPG の結果を反映しステイクホル ダーの意志決定の一部を一般に説明するものであるとい う評価であった .なぜならば, "Close to Ubon = yes" かつ "Previous Seed Class" の值がより大きい場合は， “Accessibility of RRC” か業者決定の要素になり，都市 部でよりアクセスしやすい $\mathrm{AC} / \mathrm{DAO} / \mathrm{SC}$ か RRC が選 択されていることや , "Close to Ubon = yes" と限定付 きではあるが "Previous Seed Class” の值がより小さい 場合は，Own Stock (OS) を選択するという専門家の仮 説の本質的部分が反映された形となったからである. 基 本的な構成は問題なかったが, "Previous Seed Class" の閾値が 0 であることは仮説での値 $(2$ あるいは 3$)$ と は違っており問題となった。しかし，これは RPG ログ をエージェントに与え可視化した場合にも同樣の現象を 専門家か確認しており，RPGでも実際に起こった現象と して理解されることとなった .

仮説 (図 5) と学習モデル (図 6 右) の違いから次の検 討課題が得られた . まず, 学習モデルと仮説との目立っ た違いは, "Previous Seed Class" の閾值である.この 現象は，RPG という環境の中のみで起こるものであるの か (RPG では金のやり取りは仮想的であったため容易に 米力購入されていた可能性がある)，一般的に起こるもの であるのか検討する必要が示唆された . また , 仮説に含 まれた2つの属性 (Change Variety, Original Supplier is RRC) は結果に含まれなかった . 兴の原因としてデー 


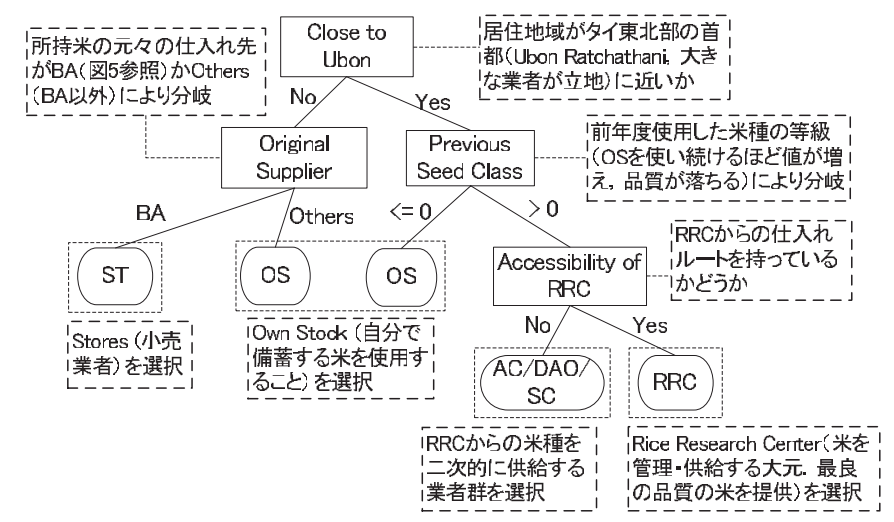

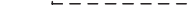

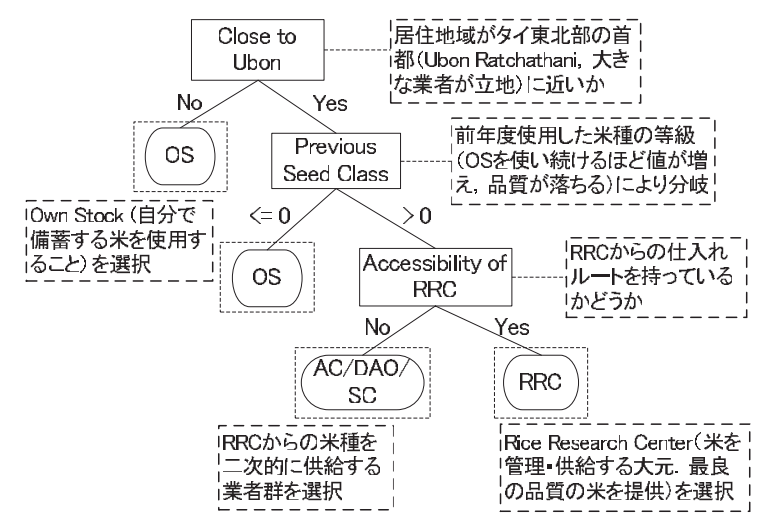

と専門家の評価後改良された学習結果 (右)
タが十分でなかったことも考えられ，弚の重要性につい て検討する必要が示唆された . また, 結果の中には十分 にステイクホルダーの行動を説明していると言い切れな いものもあり(例えば， "Close to Ubon = no -> OS" では，都市から離れているだけで必ず OS を選ぶとは考 えにくい)，今回データに含めた属性以外で尃門家が気付 いていない重要な属性が存在する可能性があり, これも 検討課題となった .これらの課題は, ステイクホルダー への追跡調査, 専門家間の議論, 及び, 今後の RPG に より検討される必要がある.

\section{$5 \cdot 4$ 本手法の考察}

今回採用した接近法の有効性を次のように確認した . まず，属性選択手法の利用に関しては，専門家による学 習結果の精錬の手間を軽減されるものとなった . 今回の 例では, 属性選択手法を利用しない場合, 即ち, 専門家に よる属性の絞り込みだけを行う場合，属性の削除と C 4.5 を適用する修正プロセスを 3 回要したのに対し, 使用し た場合は1回で済んだ (図 6 左から “Original Supplier” を削除したのみ）. 今回の例題以外においても，属性選 択手法が尃門家への負担を軽減するために効果を挙げた . 今回のように可視化手法を用いる場合は光の準備コスト を考えると，弚の回数がより少ない方が望ましく，本プ 口セスは不可欠と考えられる . また，属性選択の過程で， 仮説である決定木から抽出した重要な属性は除外しない こととしたが, これを行わない場合，専門家が重要と考 える属性も除外されてしまい, 結果的に専門家が納得す る結果を得ることか難しくなった場合があった．

次に, 学習されたモデルの可視化による評価法は，モ デルの持つ特性をより理解し，より中立的にモデルを評 価するために役立ったと考えられる.$R P G$ と同じ状況を 再現しているために, 専門家は各ステップでェージェント の意志決定結果について樣々な意見を述べることができ た。これは, 当初に決定木だけ示していたときよりも多 くの意見を引き出すことができた . 今回の例では, 農村 部の農民に関してはほとんど “OS”が選択されるのに対 し，最初のステップの一部のみが “ST” を選択したため，
谷の特異な状況を簡単に把握することができ，続いて产 れに対応する属性の除外が容易に行われた．また，結果 的に属性の除外はされなかったものの, "Previous Seed Class" の閾值が 0 だったために ,一部のエージェントに おいて OS と光の他の業者が交代で表示される結果とな り，乥の状況について特に多くの発言を得た . 専門家の 仮説と相違があったにもかかわらずこの現象が受け入れ られたのは，RPG ログをエージェントに与えた場合に 示された結果も似た現象を示されたからであり，専門家 がより中立的に評価できたという点でこの方法の有効性 を示している．また，以上については，決定木を直接見 せるよりも達成が容易と考えられ，視覚的に結果を見せ ることの利点を示している。

本手法により得られたモデルは, RPG ログから抽出 できる最も一般性の高く唯一のものと言い切ることはで きない．しかしながら，属性選択手法ができるだけ予測 精度を向上させることでモデルの一般性を高め, さらに 可視化によって専門家が学習モデルをより深く理解し精 錬することで, 専門家が納得できるモデルを提供できた と考える．したがって，専門家は仮説との比較より得ら れた検討課題を真摰に受け止め, 今後兴の解決のため取 り組むことができ，この点が特に重要である．

今後, 弚の他の例題を取り上げることによりさらに本 手法自体の評価・精錬を行う必要があるが, 機械学習に より人手で同時に扱うには困難な数の属性組から，専門 家の仮説を検証するための価値のあるモデルを提供する 体系的な手法を提供できたと考える .

\section{6. おわりに}

本研究では, 参加型モデリングにおいて, RPG ログ データに対し分類学習を適用する新しいェージェントモ デル構築法を提案した . 本手法により，モデル構築者の 能力に依らず，多くの要因を一度に扱うことのできる体 系的なモデル構筑を行うことができる．分類学習を適用 する際の問題としては，1) データ収集コストが大きいた め，属性の数に比べ十分な事例が得られない，2) データ 量の不十分さゆえにノイズが学習結果に影響を及ぼす可 
能性が高い．3) 学習結果を構成する分類条件は，人間の 意志決定モデルとして説明でき，専門家を納得させるも のでなくてはならない,の 3 点である。これに対し，我々 は，1）専門家が重要と判断する属性は残しつつ, 属性選 択手法により初期属性集合から予測精度が最も高くなる 属性集合を同定し，2）実施した RPG と同じ環境と参加 者をコンピュータ上でグラフィカルインタフェースとェー ジェントとして再現し，弚の条件下でェージェントに学 習モデルを与え，意志決定結果を示すことで理解促進を 図り，機械学習から得た結果に含まれる不適切な属性を さらに除外する，という属性選択の手法によりエージェ ントモデル構築システムを実現し，問題の解決を行った . 最後に, 実際に, タイ東北部の農業経済の参加型モデリ ングに参加し，当該の専門家と共に評価することで，本 手法の有効性を確認した .

本論文の意義は , 新たなエージェントモデル構筑法の 可能性を議論・提案し, 弚の有用性を実際例により示し たことである.これまでに RPG ログから機械学習を用 いて現実を反映するモデルを得る体系的な手法の研究は なかった言える．東南アジア，アフリカ，ヨーロッパで 樣々な事例 [Bousquet 02] に適用され，研究が進んでい る参加型モデリングは, 本研究により工学的な支援を得 ることでさらに方法論として充実したものとなる . 今後 弚の他の属性選択手法や演繹学習を含め他の学習手法を 適用することで，機械学習によるエージェントモデル構 築手法の更なる充実が期待される .

\section{謝辞}

本研究の手法に対しご助言いただいた CIRAD の Guy Trébuil 氏, Ubon Ratchatani 大学の Chirawat Vejpas 氏の両氏に心より感謝の意を表す . また , 本研究は, 21 世紀 COE「知識社会基盤構築のための情報学拠点形成」 若手研究者育成プログラム, 日本学術振興会科学研究費 基盤研究 (A)15200012 の助成金により行われた .

\section{$\diamond$ 参 考 文 献 $\diamond$}

[Almuallim 94] Almuallim, H. and dietterich, T. G. Learning Boolean Concepts in the Presence of Many Irrelevant Features. Artificial Intelligence, Vol. 69, pp. 279-305, 1994.

[Bousquet 98] Bousquet, F., Bakam, I., Proton, H. and Le Page, C. Cormas: common-pool resources and multi-agent Systems. Lecture Notes in Artificial Intelligence, Vol. 1416 pp. 826-838, 1998.

[Bousquet 99] Bousquet, F., Barreteau, O., Le Page, C., Mullon, C. and Weber, J.: An environmental modelling approach. The use of multi-agent simulations. Blasco $\mathrm{F}$ and Weill A (Eds.) Advances in environmental and ecological modeling, Elsevier, pp. 113-122, 1999.

[Bousquet 02] Bousquet F., Barreteau O., d'Aquino P., Etienne M., Boissau S., Aubert S., Le Page C., Babin D., Castella J.C.: Multi-agent systems and role games: an approach for ecosystem co-management. In: Janssen M. (eds) Complexity and Ecosystem Management: The Theory and Practice of Multi-agent Approaches. Edward Elgar Publishers, pp. 248-285, 2002.
[Gilbert 99] Gilbert, N. and Troitzsch, K. G.: Simulation for the social scientist. Milton Keynes: Open University Press. 1999.

[Gilbert 02] Gilbert, N., Maltby, S. and Asakawa, T.: Participatory simulations for developing scenarios in environmental resource management. In Proceedings of Third Workshop on Agent-Based Simulation, pp. 67-72, 2002.

[Helbing 00] Helbing, D., Farkas, I.J. and Vicsek, T.: Simulating Dynamical Features of Escape Panic. Nature, 407(6803), pp. 487-490, 2000.

[石野 95] 石野洋子, 寺野隆雄 : 模擬育種法と帰納学習を適用し たマーケティング情報分析, 人工知能学会誌, Vol. 12 , No. 1, pp. 121-131, 1997.

[Kita 03] Kita, H., Sato, H., Mori, N. and Ono, I.: U-Mart System, Software for Open Experiments of Artificial Market, In Proceedings of IEEE International Symposium on Computational Intelligence in Robotics and Automation, pp. 1328-1333, 2003.

[Kohavi 97] Kohavi, R. and John, G.: Wrappers for feature selection. Artificial Intelligence, Vol. 97, pp. 273-324, 1997.

[Murakami 03] Murakami, Y., Ishida, T., Kawasoe, T. and Hishiyama, R.: Scenario Description for Multi-Agent Simulation. In Proceedings of International Joint Conference on Autonomous Agents and Multiagent Systems (AAMAS-03), pp. 369-376, 2003.

[Quinlan 86] Quinlan, J. R.: Induction for Decision Trees, Machine Learning, Vol. 1, No. 1, pp. 81-106, 1986.

[Quinlan 93] Quinlan, J. R.: C4.5: Programs for Machine Learning, Morgan-Kaufmann, 1993.

[Vejpas 04] Vejpas, C., Bousquet, F., Naivinit, W., Trébuil, G., Srisombat, N. Participatory modeling for managing rainfed lowland rice variety and seed systems in lower northeast Thailand, Mekong Rice Conference, OS3.4, 2004.

\section{〔担当委員 : 柏原 昭博〕}

2005 年 5 月 2 日 受理

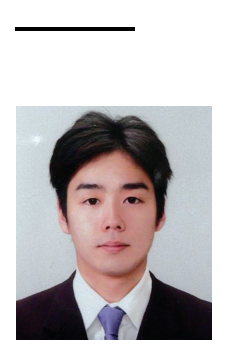

\section{紹 介}

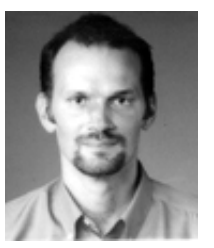

鳥居 大祐(学生会員)

2001 年京都大学工学部情報学科卒. 2003 年同大学院社会 情報学専攻修士課程修了. 現在, 同大学院社会情報学専攻 博士課程に在学中. 機械学習, マルチェージェントシミュ レーション, P2P システムに興味を持つ。

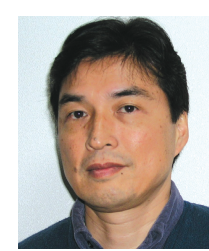

ブスケ フランソワ

1994 年リヨン第一大学にて生物数学の博士号を取得 . 1993 年よりフランスの国際農業研究所 (CIRAD) に所属し, 現 在, チュラロンコーン大学との共同プロジェクトにてタイ を活動の中心に置く . 再利用可能な資源管理のシミュレー ションのためにマルチェージェントシステムの開発や利用 に興味を持つ

\section{石田亨(正会員)}

1976 年京都大学工学部情報学工学科卒業, 1978 年同大 学院修士課程修了. 京都大学大学院情報学研究科社会情報 学専攻教授. 工学博士. IEEE Fellow . 情報処理学会フエ ロー . 人工知能, コミュニケーション , 社会情報システム に興味を持つ。 